\title{
Traditional Javanese Wooden Houses (Joglo) Damaged By May 2006 Yogyakarta Earthquake, Indonesia
}

\section{$\operatorname{AUTHOR}(S)$ :}

Prihatmaji, Yulianto P.; Kitamori, Akihisa; Komatsu, Kohei

\section{CITATION:}

Prihatmaji, Yulianto P.... [et al]. Traditional Javanese Wooden Houses (Joglo) Damaged By May 2006 Yogyakarta Earthquake, Indonesia. International Journal of Architectural Heritage: Conservation, Analysis, and Restoration 2013, 8(2): 247-268

\section{ISSUE DATE:}

2013-10-28

URL:

http://hdl.handle.net/2433/199253

\section{RIGHT:}

This is an Accepted Manuscript of an article published by Taylor \& Francis in "International Journal of Architectural Heritageon", available online: http://www.tandfonline.com/10.1080/15583058.2012.692847.: This is not the published version. Please cite only the published version.; この論文は出版社版でありません。引用の際には出版社版をご磼認じ 利用ください。 


\title{
An Investigation of Traditional Javanese Wooden Houses 'Joglo’ Damaged during the May 2006 Yogyakarta Earthquake, Indonesia.
}

\author{
Yulianto P Prihatmaji ${ }^{1,4 *}$, Akihisa Kitamori ${ }^{2}$, Kohei Komatsu ${ }^{3}$ \\ ${ }^{1}$ Doctorate Candidate, Research Institute for Sustainable Humanosphere, Kyoto University \\ Wood Hall 2F, Gokasyou, Uji, Kyoto 611-0011, Japan. \\ Tel. : : $+81-774-38-3670$ \\ Fax. : : $+81-774-38-3678$ \\ E-mail : prihatmaji@rish.kyoto-u.ac.jp \\ ${ }^{2}$ Assistant Professor, Research Institute for Sustainable Humanosphere, Kyoto University \\ Wood Hall 2F, Gokasyou, Uji, Kyoto 611-0011, Japan. \\ Tel. : : $+81-774-38-3675$ \\ Fax. $\quad:+81-774-38-3678$ \\ E-mail : kitamori@rish.kyoto-u.ac.jp \\ ${ }^{3}$ Professor, Research Institute for Sustainable Humanosphere, Kyoto University \\ Wood Hall 2F, Gokasyou, Uji, Kyoto 611-0011, Japan. \\ Tel. : : $+81-774-38-3674$ \\ Fax. : : $\quad$ +81-774-38-3678 \\ E-mail : kkomatsu@rish.kyoto-u.ac.jp \\ ${ }^{4}$ Lecturer, Department of Architecture, Islamic University of Indonesia \\ Jl. Kaliurang Km 4 Yogyakarta 55584, Indonesia \\ Tel. $\quad$ : +62274896440 \\ Fax. $\quad:+62274895330$ \\ E-mail : prihatmaji@staf.uii.ac.id
}

\begin{abstract}
A post-earthquake survey was performed on Joglo Javanese wooden houses, seriously affected by the May 27, 2006 Yogyakarta earthquake in Java, Indonesia. Investigations on 20 damaged Joglo buildings reveal that the structure's damage can be classified into 3 categories: slip between columns and stone foundation, broken joints between outer ring beam and column, and collapse of core structure. Four damage levels were defined: I) damage on the base joint of side structure, II) fatal damage on the side-structure, III) destroyed core structure, and IV) totally collapsed core structure. The side structure turns out to be relatively weak, while the core structure is able to secure the structural performance of Joglo buildings. A distinct relationship was identified between the levels of structural damage and the area ratio of core structure and the main column projection. It was verified that structural proportion significantly contributes to the assessment of damage. The joint failure represents a significant point in terms of maximum retention for conservation. Based on a damage level approach, an assessment methodology to optimize reinforcing strategies. This paper gives recommendations for the preservation of such precious structures from future earthquakes, while avoiding inappropriate interventions.
\end{abstract}

KEY WORDS: Joglo house; wood structure; assessment of earthquake damage; structural proportion; cultural heritage building preservation.

\section{INTRODUCTION}

The timber buildings known as 'Joglo' represent the Javanese traditional architecture, heritage, art and culture. Joglo buildings are unique because of their peculiar construction with joints made of several massive pieces of timber which are stacked, creating a complicated roof structure. Yogyakarta is located in a high risk seismic area, which is regularly affected by destructive earthquakes. Traditional timber buildings, particularly Joglo buildings, were severely damaged, and in some cases destroyed by the May 27, 2006 Yogyakarta earthquake. Hence, an appropriate assessment method should be established. Through this method, we identify their vulnerability and provide advice for strengthening strategies, thus minimizing alterations and depreciation.

The 6.3 moment magnitude $\left(\mathrm{M}_{\mathrm{W}}\right)$ earthquake on May 27, 2006 inflicted massive damage on many

\footnotetext{
* Corresponding author, Tel: +81 774383670, Fax: +81 774383678, E-mail: prihatmaji@rish.kyoto-u.ac.jp.

Present E-mail : prihatmaji@uii.ac.id
} 
buildings in Yogyakarta. Many Joglo buildings were unable to withstand this potent magnitude. Postearthquake surveys have been carried out by many researchers. Table 1 gives the post-earthquake damage level of Joglo buildings from 3 sources (Sulistiana, 2007; Adishakti, 2008; Wahyudi, 2008).

Table 1. The number of traditional houses and Joglo building damages

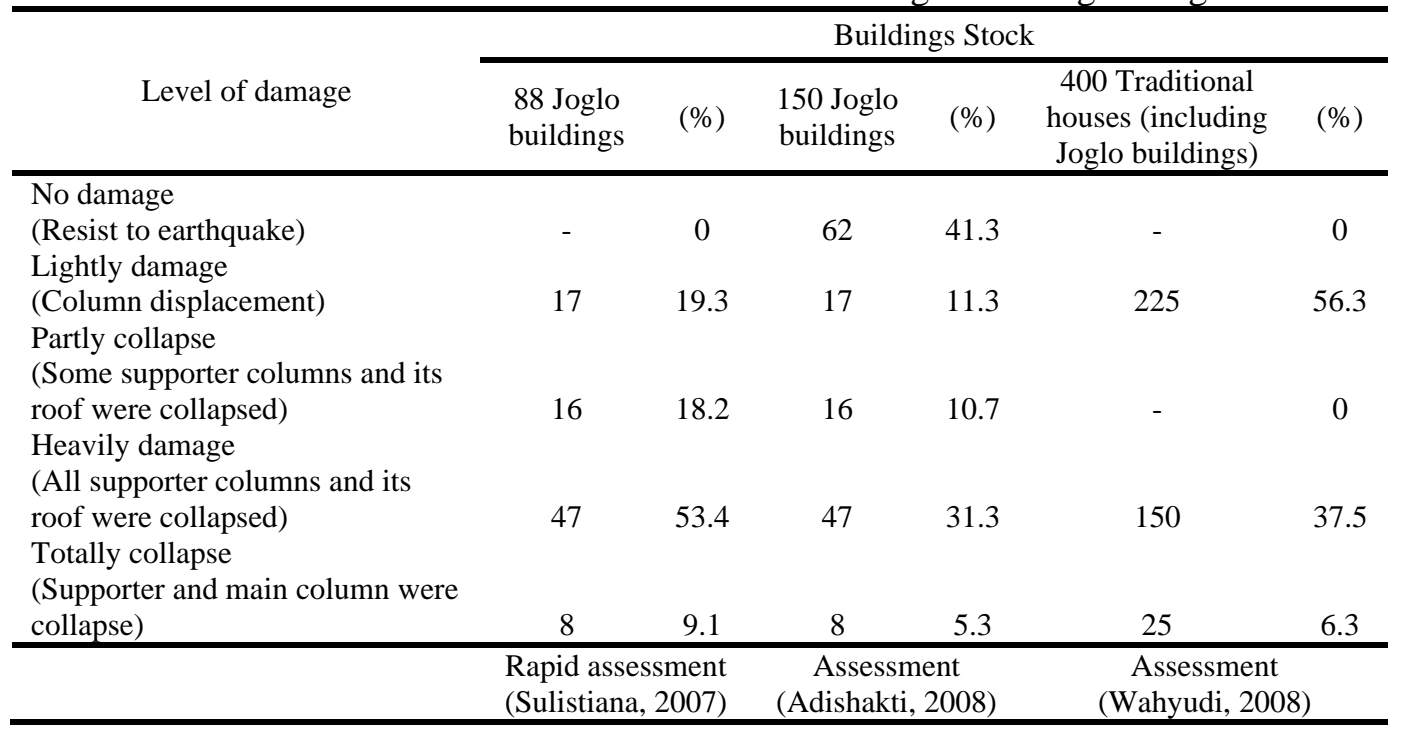

The estimation of totally collapsed traditional houses is between 5 to $9 \%$. If we combine this amount with the heavily damaged houses and partly collapsed ones, this percentage increases until the range by 40 to $80 \%$. This percentage shows the critical needs for total reconstruction of traditional houses, in order to preserve those disappearing buildings as valuable and tangible culture.

Understanding the damages of Joglo buildings provides important clues to reinforce buildings, anticipate future disasters, as well as conducting post-earthquake repairs. Such buildings have managed to survive for such a long period, resisting and enduring the frequent seismic events, which are mainly attributed to their structural system (Vissilia et al., 2010). This is why these buildings seem to fulfill the requirements of the seismic areas. Understanding the damages of Joglo buildings will lead us to very important clues on how to reinforce buildings, anticipate future disasters, as well as conducting post-earthquake repairs. Generally, buildings with traditional structure systems could be applied in earthquake prone areas to reduce human casualties and economic loss (Dogangun et al., 2006).

The Joglo buildings were built during a period when construction standards and codes did not exist in Indonesia; hence, it is hard to classify them from an engineering point of view (Ronald et al, 1987). Until now, the Indonesian government was not engaged with the systematic characterization of wooden architecture (Budiono, 2004). Therefore, we urge to provide codes and standards for timber buildings (Yahmo, 2007), especially identification and classification of earthquake-damaged timber structures.

Nowadays, a performance-based assessment procedure for Javanese Joglo construction is required. A reliable evaluation of the current load-bearing state of the building is required to access its resistance to future earthquakes and the quality assessment of its materials (Vissilia et al., 2010).

We partially focused on timber structure, especially on the traditional rules of the Javanese architecture and their structural proportion (Prihatmaji et al., 2011). After the May 27, 2006 Yogyakarta earthquake, a survey was carried out targeting the Joglo structures without walls. A comparison analysis highlights a relationship between structural proportions and the damage levels of the structures. The results are checked to confirm the estimation method of structural vulnerability of Joglo buildings. 


\section{BRIEF OF YOGYAKARTA EARTHQUAKE ON MAY 27, 2006}

A moderate-to-strong $6.3 \mathrm{M}_{\mathrm{W}}$ earthquake (body wave magnitude, $\mathrm{M}_{\mathrm{b}}$ 5.9) struck the southernmiddle Java island in the very heartland of Indonesia at 5:54 local time on May 27 2006, causing widespread severe destruction, including loss of lives and properties (USGS, 2007).

According to the information provided by the US Geological Survey (USGS), the epicenter of the earthquake was located at $7.9620^{\circ} \mathrm{S}-110.4580^{\circ} \mathrm{E}$ or $20 \mathrm{~km}$ SSE of Yogyakarta, which was severely affected, and $455 \mathrm{~km}$ ESE of Jakarta, with a focal depth of $10 \mathrm{~km}$ (USGS, 2007). BMG (Indonesian Meteorological and Geophysical Agency) published the following information: the magnitude was 5.9 Righter scale and the epicenter was at $8.03^{\circ} \mathrm{S}-110.32^{\circ} \mathrm{E}$ with $11.8 \mathrm{~km}$ depth, $37 \mathrm{~km}$ from Yogyakarta (BAPPENAS, 2007).

Elnashai et al., (2006) estimates the dimensions of the presumed fault rupture as $20 \mathrm{~km}$ in length and $10 \mathrm{~km}$ in width. In the case of the dispersion of the Peak Ground Accelerations (PGA), the maximum recorded values are 0.49g (Bantul) and 0.41g (Yogyakarta City). The record at the YOGI station and BJI station are about $10 \mathrm{~km}$ and $90 \mathrm{~km}$ distances from the epicenter, respectively. By considering the vertical ground motion, the PGAs are $0.47 \mathrm{~g}$ and $0.38 \mathrm{~g}$ (Elnashai et al, 2006).

Based on data reported by National Development Planning Agency of Indonesia (BAPPENAS, 2007), the earthquake killed 4,659 people and injured 19,401 people in Yogyakarta Special Province. In central Java province, 1,057 people died, and 18,526 were injured. The earthquake destroyed 88,249 houses and damaged 98,343 in Yogyakarta province. In central Java province, 68,415 houses were destroyed and 103,689 houses were damaged.

Table 2. Historical earthquakes around Yogyakarta area (Paku Alam VI, 1977; BAPPENAS, et al., 2007)

\begin{tabular}{|c|c|c|c|c|c|c|c|}
\hline \multirow[b]{2}{*}{ Year } & \multirow[b]{2}{*}{ Month } & \multirow[b]{2}{*}{ Date } & \multicolumn{2}{|c|}{ Epicenter } & \multirow{2}{*}{$\begin{array}{c}\text { Distance between } \\
\text { epicenter and } \\
\text { Yogyakarta city }(\mathrm{km})\end{array}$} & \multirow{2}{*}{$\begin{array}{l}\text { Ms, Intensity, or } \\
\text { the reported } \\
\text { description }\end{array}$} & \multirow{2}{*}{$\begin{array}{l}\text { Depth } \\
(\mathrm{km})\end{array}$} \\
\hline & & & $\begin{array}{l}\text { Latitude } \\
\text { (South) }\end{array}$ & $\begin{array}{c}\text { Longitude } \\
\text { (East) }\end{array}$ & & & \\
\hline 1867 & June & 10 & - & - & - & MM > VIII & - \\
\hline 1903 & February & 27 & 8.00 & 106.00 & 143 & 7.9 & 25 \\
\hline 1921 & September & 11 & 11.35 & 110.76 & 385 & 7.5 & - \\
\hline 1937 & September & 27 & 8.88 & 110.65 & 330 & 7.2 & - \\
\hline 1962 & December & 21 & 9.00 & 112.40 & 103 & 6.27 & - \\
\hline 1977 & August & 19 & 11.16 & 118.41 & 250 & 7.9 & 33 \\
\hline 2006 & May & 27 & 7.96 & 110.46 & 20 & 6.3 & 10 \\
\hline 2006 & July & 17 & 9.22 & 107.32 & 303 & 7.7 & 34 \\
\hline
\end{tabular}

Note: Distance closer than 200km or Magnitude greater than 7.0 are listed. During the period 1982 to 2006, no data of the earthquakes with magnitude over 6.0

The BMG, in BAPPENAS (2007), published that Java-island has been frequently exposed to moderate-to-destructive earthquakes, as shown in Table 2. Furthermore, Java is one of Indonesia's main-islands characterized by earthquakes of medium return period (50 - 100 years) that cause loss of properties and lives. Earthquakes in Java are generally both in-land and offshore type and shallowfocus-earthquakes which are strong and destructive even when their magnitude is not considerably high (Siddiq, 2006).

Based on codex of the Babad Pakualaman, a major earthquake had struck Yogyakarta on June 10th, 1867 (Paku Alam VI, 1977). At that time, some cultural heritage buildings collapsed: the ancient city of Kotagede, several buildings in the fortress of Sultan's palace, tombs of the kings of Imogiri, main hall of Pakualaman palace and main hall of grand mosque of Yogyakarta.

The May 27, 2006 Yogyakarta earthquake hits several important Joglo buildings, such as Trajumas hall in Sultan's palace (Santosa and Prihatmaji, 2010; Suwito, 2009), Djojodiningratan royal house, Brontokusuman royal house, and Taman Siswa hall (Siddiq, 2006). Moreover, Yogyakarta's Heritage Trust reported that 88 Joglo buildings in Kotagede were either damaged or collapsed (JHS, 2007).

\section{TYPICAL JAVANESE WOODEN STRUCTURES}

\subsection{Types of Javanese Wooden Houses}

The traditional Javanese timber buildings in Java are influenced by the historical Javanese timber construction used about hundreds of years ago. There are four types of Javanese traditional houses 
based on the roof shape: joglo, limasan, kampung and panggangpe (Ismunandar, 1997), as shown in Figure 1a-d. Joglo is the most complicated and sophisticated type in terms of construction and timber joint techniques, whereas panggangpe is the simplest (Tjahjono, 1989). The Joglo type uses teakwood (Tectona grandis) as the primary construction material for both the structure and the ornaments. Mortise and tenon are used for the connections in this type of building.

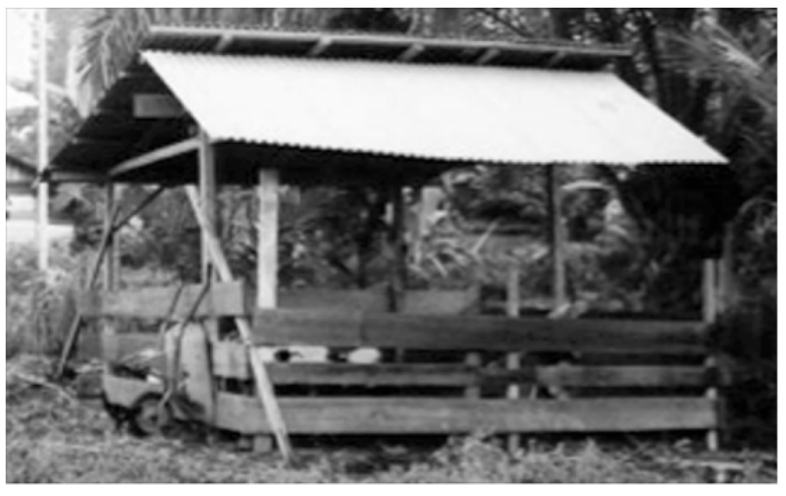

(a)

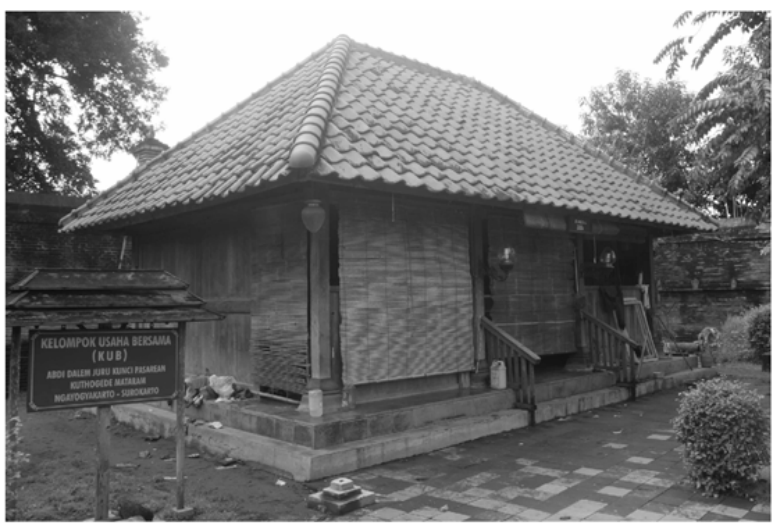

(c)

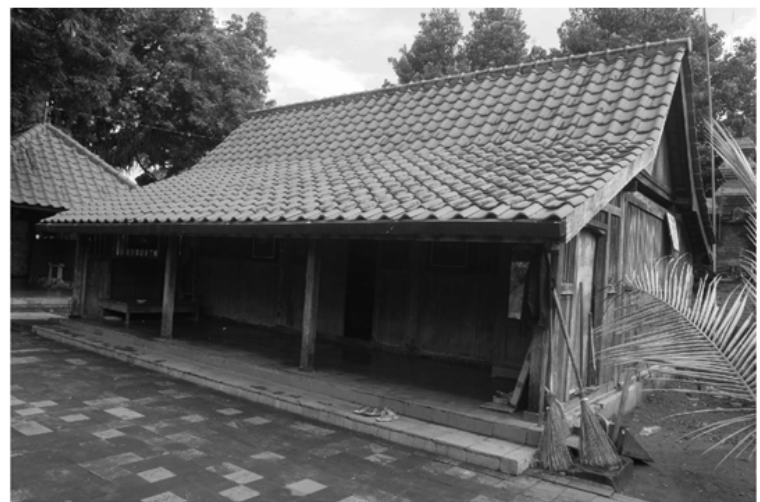

(b)

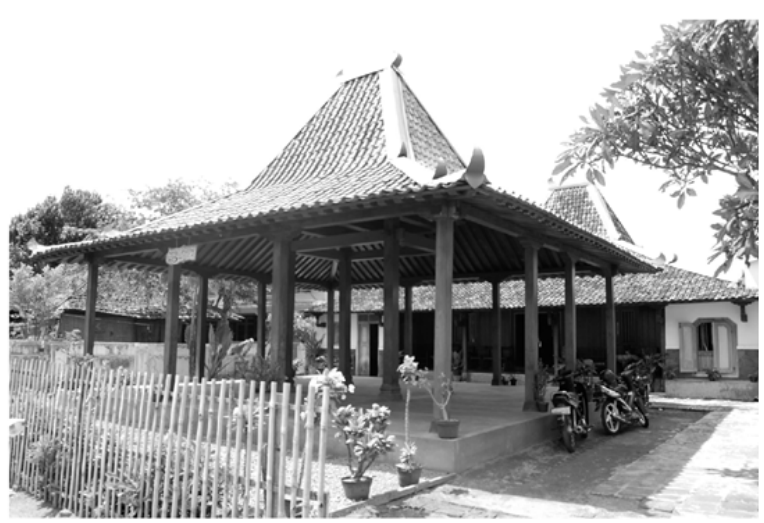

(d)

Figure 1. Types of Javanese traditional house based on the roof form.

(a) Panggangpe, (b) Kampung, (c) Limasan, (d) Joglo.

This article deals only Joglo type construction. Some of the most important structural characteristics and distinctive features of the Joglo type are: a) inner core structure and surrounding outer structure 3dimensionally symmetric, b) the core structure has larger member (height, width and length) than those used in the outer structure, c) the core structure is stiffened by massive mortise and tenon joints used at the four main columns, d) outer structure is flexibly linked to the core structure by rafter beams, e) the joints of outer structure are relatively simpler than that of core structure, f) the horizontal plane of the core structure is massive enough due to both the outer pyramid composition and inverted pyramid in the top of core structure, g) the horizontal plane of outer structure is lightly impressed, and h) column legs of the core structure and side structure are not tied together to each other.

\subsection{Structural Details of Joglo}

The roofs are the primary elements in determining the type of Javanese traditional building, just as columns are in Western Classical architecture. A Joglo building's roof uses the plane system materialized by a wide flat-wise rafter and wooden lath. There are two types of rafter arrangements (Santosa and Prihatmaji, 2010), as shown in Figure 2. In one hand, the fishbone rafter arrangement, with rafters placed radially converging to one another. In the other hand, the parallel rafter arrangement, in which as suggested by its name, the rafters are placed in a parallel configuration. 


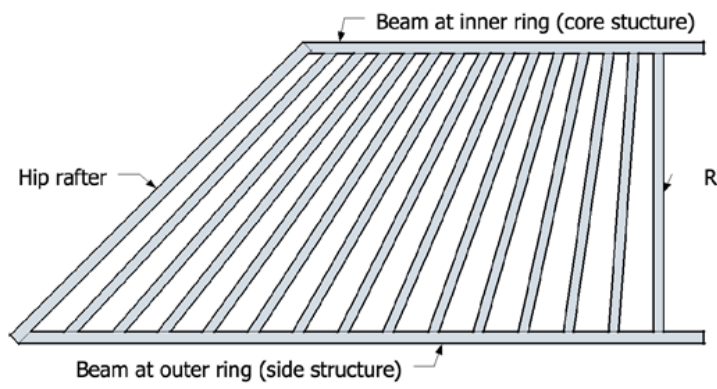

(a)

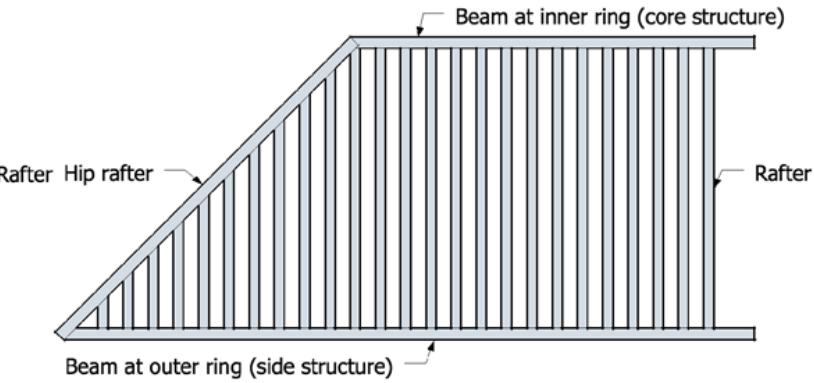

(b)

Figure 2. (a) The fishbone rafter arrangement, (b) The parallel rafter arrangement (modified from Santosa and Prihatmaji, 2010)

Joglo structures have been built using thick columns and beams, joints of column-beam (mortise and tenon system), and bracket complexes (Prihatmaji et al., 2011; Tjahjono, 1989). The columns are set on top of base stones, with column mortise embedded in stone tenon.

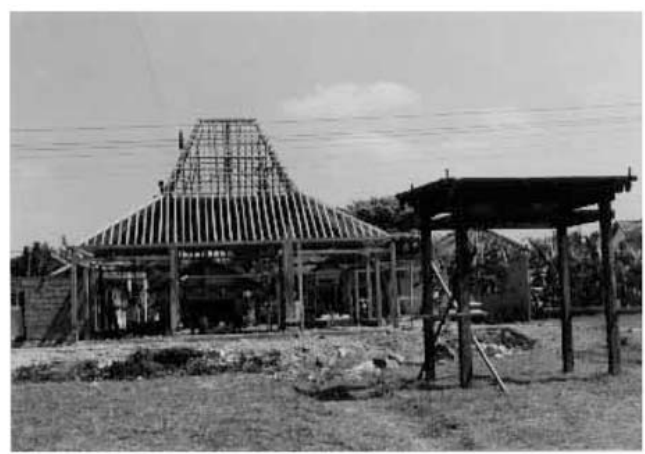

(a)

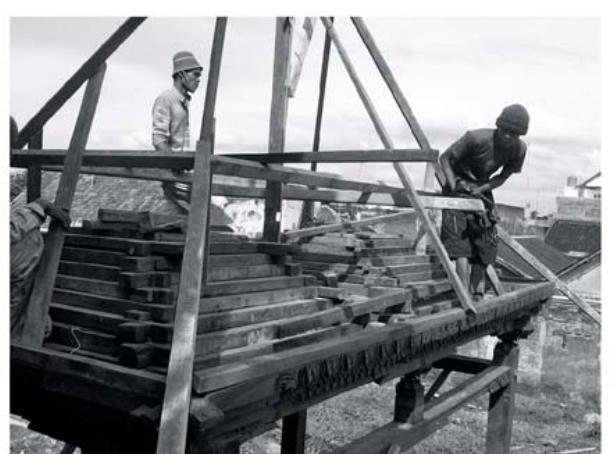

(d)

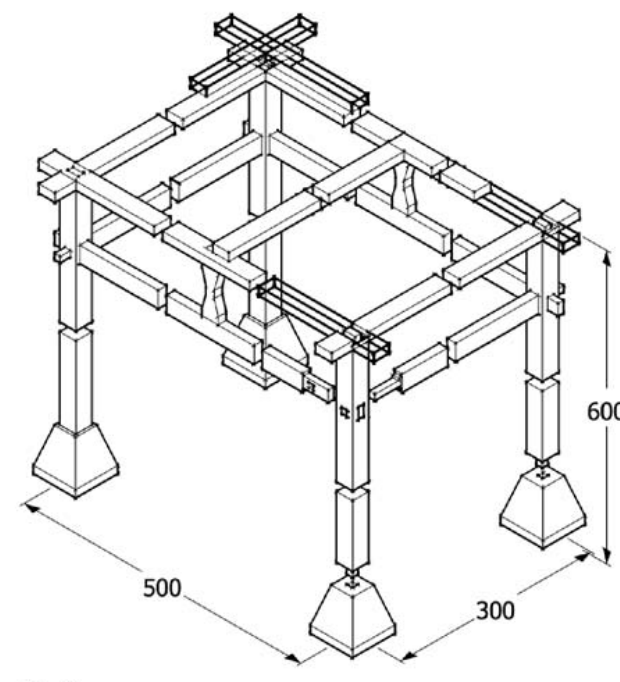

(b)

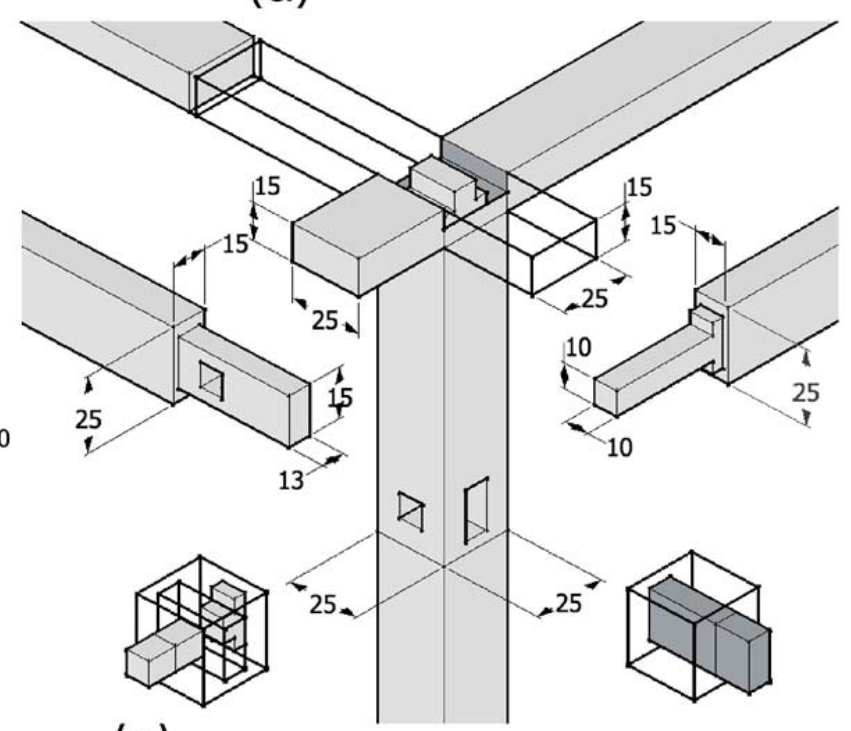

(c)

Figure 3. (a) The skeleton of Joglo building, (b) Core structure of Joglo building in detail, (c) Detail of joint construction, (d) The pyramidal ceiling on the top core structure (@ Fitri Wulandari, 2006).

The Joglo configuration can be separated into two parts; the core structure (Figure 3a-b) and the side structure. The most important details are the joints between main column and double beams, as shown in Figure 3c. Members of rather large dimension are used for the beams at core structure. 
Precise and skilled processing are the keys for the unity and stability of this particular joint (Prihatmaji, 2010c).

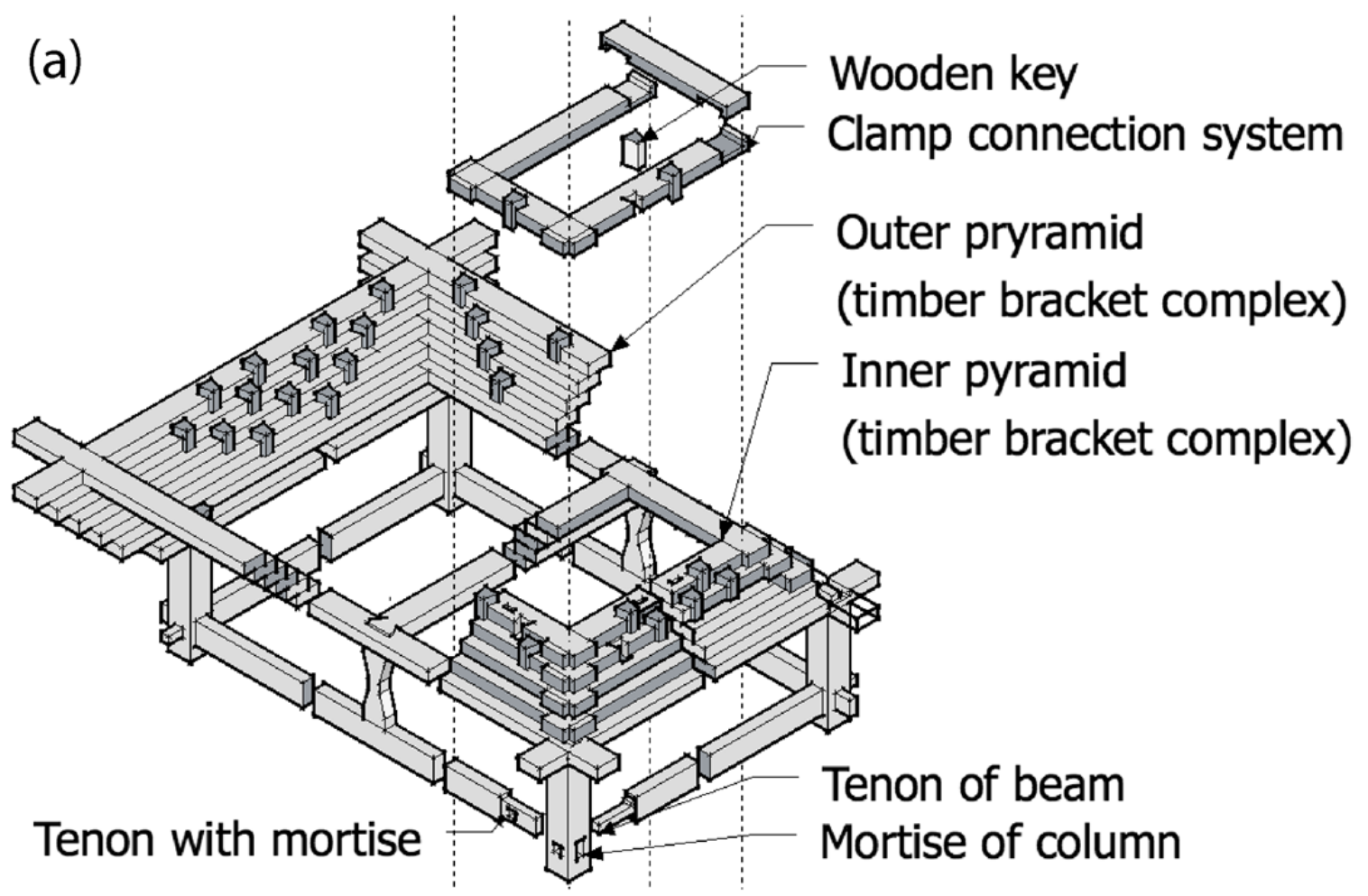

(b)

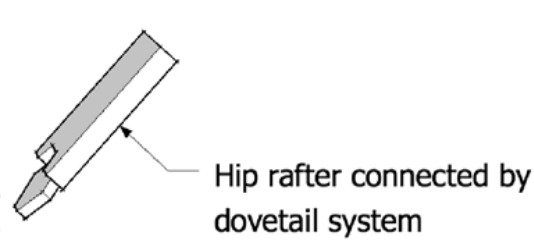

Highest beam of outer pyramid

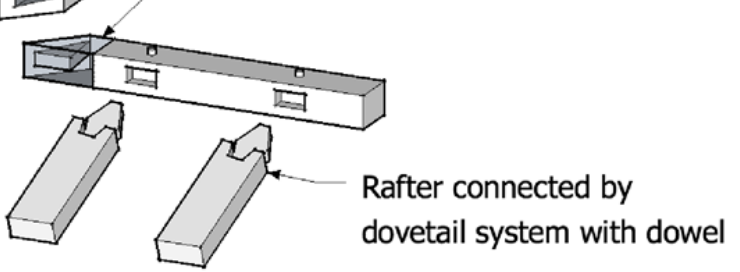

(d)

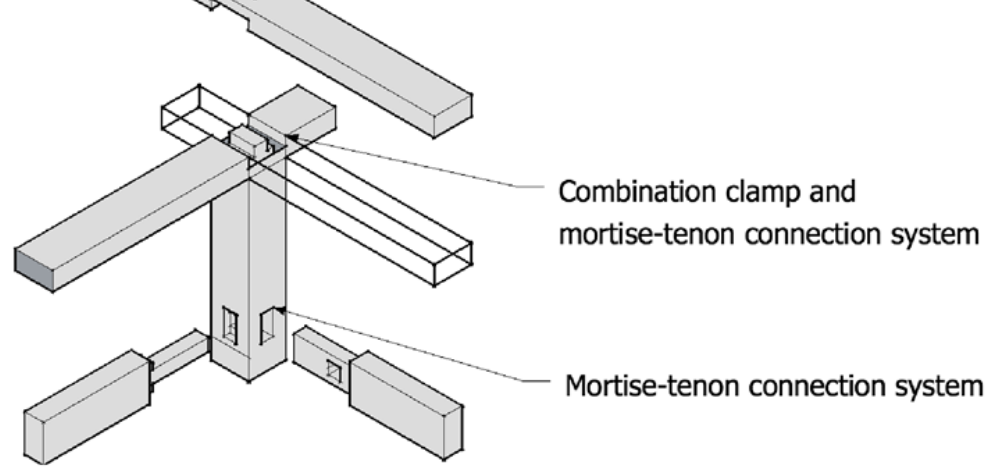

Figure 4. (a) The timber bracket complex at top of core structure, (b) Joint at corner of highest beam of outer pyramid, (c) Joint between outer ring beam, rafter and side column, (d) Corner joint of side structure.

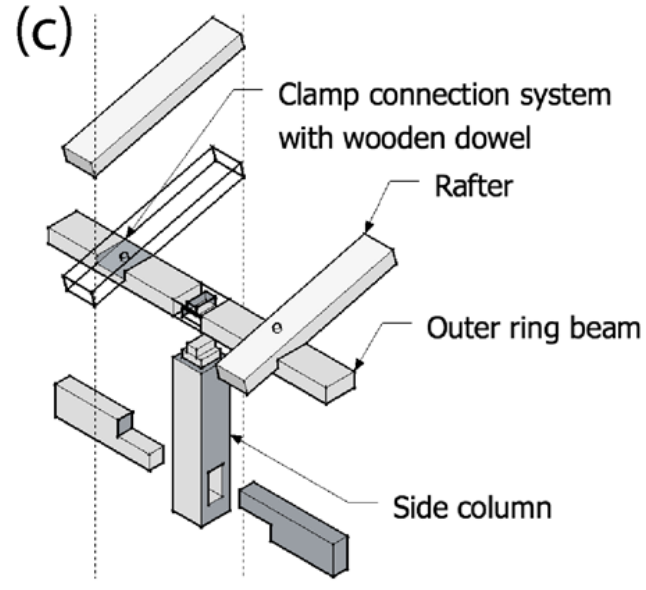


The higher beams support the heavy roof connected with the bracket complex. The lower beams are located at a slightly lower position than the roof height by interlocking each other with three parts connected at a joint consisting of columns and beams. Mortise of beams inserted to tenon of column makes a "tongue and gulls" connection. This system ties the columns together resisting pull-out force (Figure 3c). When the Joglo structure is deformed by seismic load, a rotation moment is generated inside of the joint, caused by compression resistance between beam and column.

Figure 3d shows the upper roof of the core structure resting on four main columns through a bracket complex which consists of outer and inner timber pyramids. The outer pyramid has an inverted shape surmounting the four columns. The members of pyramids are linked by a clamp system at both ends and also connected by keys between different layers (Figure 4a). This form achieves high in-plane stiffness for the ceiling of core structure. The outermost rectangular beams of the outer pyramid (highest beam) support the rafters of the roof of side structure. A rafter is used in flat-wise form and connected with the highest beam of the outer pyramid by a dovetail joint with dowel (Figure 4b).

The side structure is composed of columns and outer ring beams. It is softly combined only by rafters to the core structure. The side structure columns are almost pin supported with short mortise and tenon joint on outer ring beams, as shown in Figure 4c.

Thus, it is suggested that the core and side structures have different seismic behavior, respectively rigid and soft. The lower beam's joint of core structure grants the principal resistance factor against horizontal loads by a rotational mechanism. The core structure is usually the only part of the Joglo's buildings that survives from earthquakes (Ohno and Marcillia, 2007).

For instance we assume a common Joglo size building with 9x9 m plane area $(3 \times 4 \mathrm{~m}$ in core structure) and 5 layers of pyramid bracket complex. Using $65 \mathrm{~kg} / \mathrm{mm}^{2}$ for roof weight (roof tile, teakwood for rafter and wooden lath) and $590 \mathrm{~kg} / \mathrm{m}^{3}$ for the density of teakwood. A simple mass calculation gives the roof weight at both core and side structure as $3581 \mathrm{~kg}$ and $7217 \mathrm{~kg}$ respectively. In total, the roof weight of Joglo building is $10798 \mathrm{~kg}$.

\subsection{Structural Proportions of Joglo}

Basically, Javanese carpenter do not follow the usual units employed in modern building i.e. centimeters or inches. Due to intimate relationship between house and the owner or the master builder, the units are taken from some parts of the human body, such as kaki (feet) and kilan (the span of the open human hand from thumb to the little finger) (Ronald et al, 1987). Despite of this, we used centimeter as the measuring unit in this research, considering its reliability and validity.

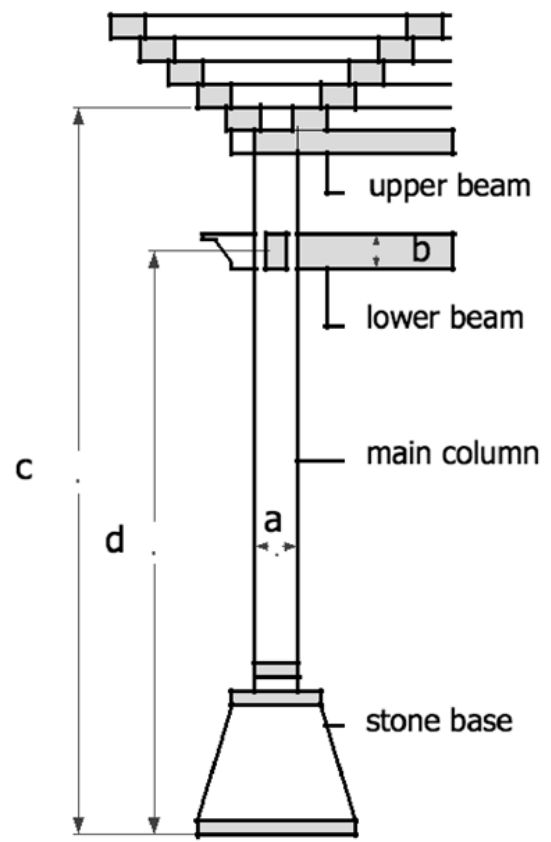

(a)

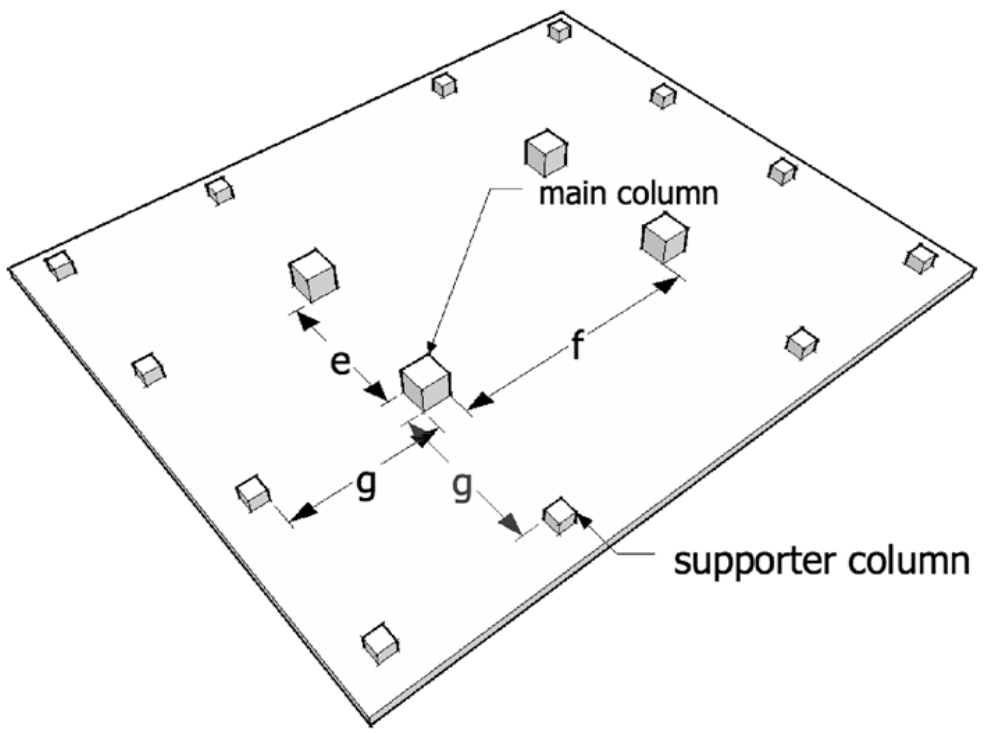

(b)

Figure 5. (a) Vertical dimension on core structure, (b) Horizontal dimensions on plan of Joglo house. 
We focused on structural proportions of Joglo structure i.e. horizontal and vertical dimensions. Structural proportions of different Joglo types were investigated. Figure 5 depicts the subjects of measurement on the Joglo's core houses.

Dimensions measured in the vertical direction are, (a) the dimension of the column (average of both width), (b) the height of the lower beam. The dimensions employed on the core structure are the following, (c) the height of column to the surface on top of the upper beam, (d) the height of the column from floor up to the centre of the lower beam. Horizontal measurements consist of three spans, (e) the width of the core structure, (f) the length of the core structure, and (g) the distance between main columns and side columns (Figure 5a-b).

\section{DETAILED INVESTIGATION OF DAMAGED BUILDING}

\subsection{Area of Investigation}

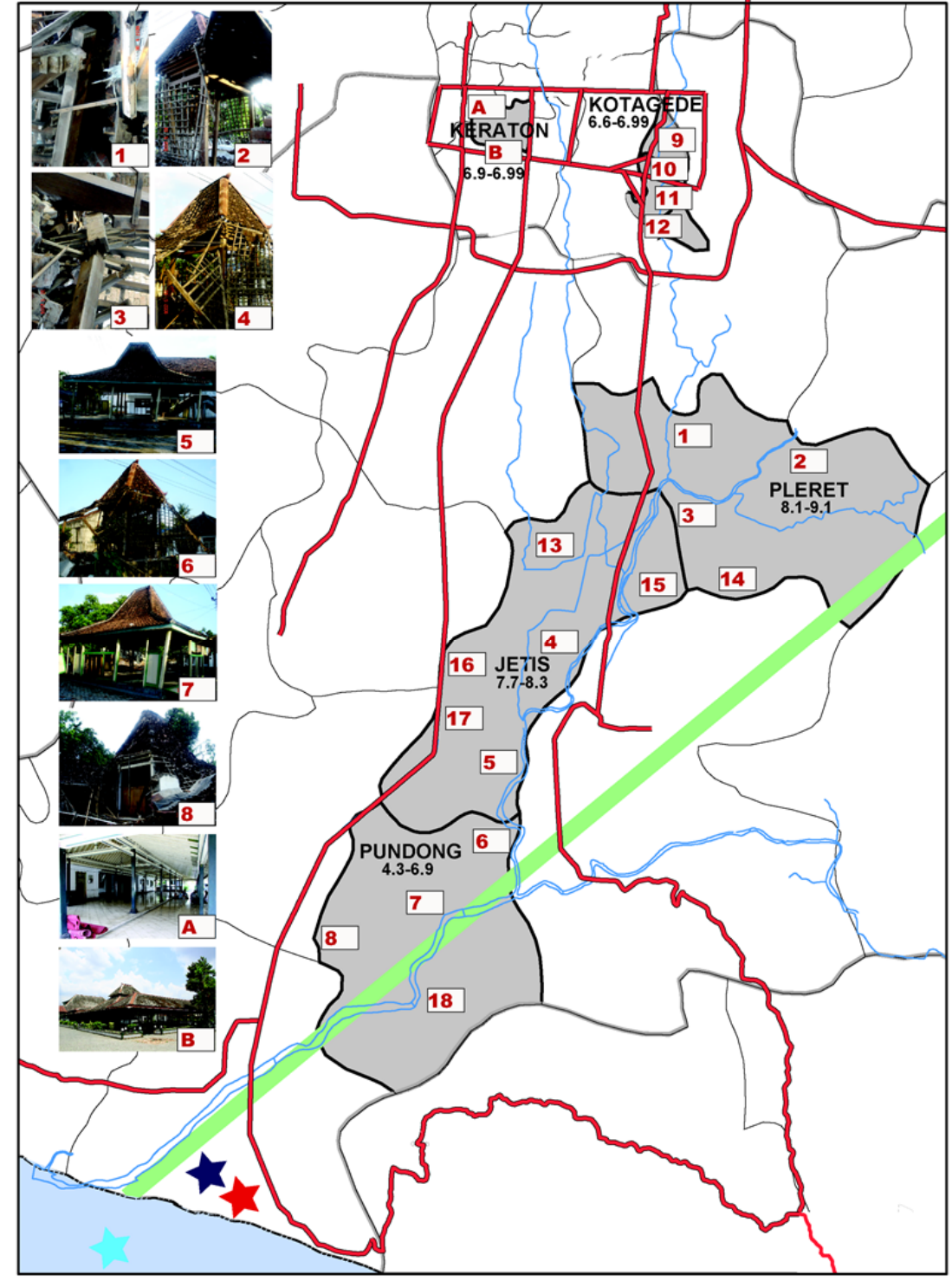

Figure 6. Area of investigation.
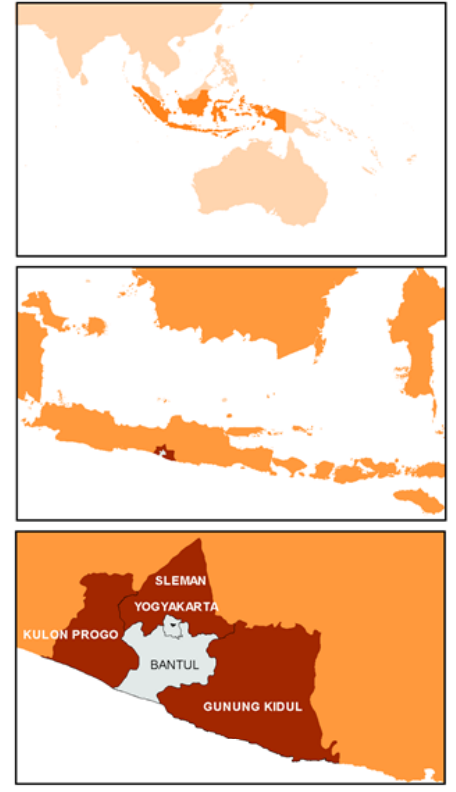

Legend

A, B, 1-18 Location of Joglo (1st stage)

A, B, 1.8 Location of Joglo (2nd stage)

$\square$ Sub-District Boundary

Sub-District Selected with Seismic Intensity based on Questioner (Murakami, 2007)

Main road

River

Opak Fault Line

BMG : 05/27/06| 5:54:01 Mb $5.9 \mid 8.03^{\circ} \mathrm{S}, 110.32^{\circ} \mathrm{E}$ Depth $11.8 \mathrm{Km}$

- USGS: 05/27/06|5:53:58 $\mathrm{Mw} 6.3 \mid 7.96^{\circ} \mathrm{S}, 110.46^{\circ} \mathrm{E}$ Depth $10 \mathrm{Km}$

- NIED : 05/27/06 | 5:53:58 $\mathrm{Mw} 6.3 \mid 7.89^{\circ} \mathrm{S}, 110.41^{\circ} \mathrm{E}$ Depth $10 \mathrm{Km}$

INVESTIGATION AREA OF JOGLO BUILDING

Yogyakarta and Bantul

The first stage of the investigation was a damage reconnaissance in Yogyakarta and Bantul, as seen in Figure 6, intending to observe the degree of damage and their structural characteristics. The area was divided into 3 groups: Pundong, Jetis and Pleret (group 1), Keraton (group 2) and Kotagede (group 3). The total number of areas in group 1 that were subjected to investigation stretched to over five sub districts. However, only three of them, Pundong, Jetis, and Pleret, were selected, based on their parallel location to the earthquake's fault line. Here, the Joglo buildings were constructed from 
1925 to 1975. The other two groups (2 and 3), Keraton (Sultan's palace) and Kotagede (ancient city of Yogyakarta), were chosen based on the existence of heritage buildings. Years of development of these buildings were from 1865 to 1921 and 1755 to 1850, respectively.

In this study, the age of the Joglo buildings is not taken into consideration since misleading structural evaluation can occur. This has to be investigating based on structural characteristics while avoiding the errors due to the different age of the material used in construction (Piazza et al., 2007). Furthermore, the quality of carpentry and regular maintenance must also be taken into account.

In this phase, 20 Joglo styled wooden houses are observed by purposive random sampling method, including 16 representative Joglo's common houses and 4 representative Joglo's royal houses. The structural damage of Joglo buildings, failure modes and contributing factors to damage are investigated and categorized.

Figure 6 represents the distribution of investigated Joglo in 4 zones (sub-district), 3 location of earthquake epicenter based on BMG, USGS and NIED Japan (National Research Institute for Earth Science and Disaster Prevention). The seismic intensities arise from questioners and pictures of each Joglo. While 20 Joglo buildings are evaluated from the damage condition, only 10 are investigated from their damage condition in relation with structural view because of their representativeness (8 Joglo common houses and 2 Joglo royal houses). Further detailed investigation including drawings with accurate dimensions is conducted, aiming to compare levels of damage and structural proportions. On-site inspection and interviews with the occupants and the owner of the house gives structural proportions of these 10 Joglo buildings.

\section{STRUCTURAL VULNERABILITY AND PRINCIPAL DAMAGE MECHANISMS Bio deterioration}

Bio deterioration for timber structure is very important. Yeo et al (2010) found that when the Taiwanese timber framework reaches a life span of approximately 112 years, the rate of timber deterioration reaches $50 \%$. The rain, leaking from the roof and the rise in dampness of the columns is responsible for deterioration of the material and damage of the structure (Lourenco et al., 2006). Such effects result in larger deformation of wooden structures after earthquakes.

The group 1 Joglo buildings were well maintained because owned by nobles and used for tourism purposes. In group 2, the Joglo buildings belong to people from the high-class society, while in group 3 , they are properties of people from the middle-class society. The investigation shows that there are few water-related problems except in the roof part and the columns. The vulnerability of timber material to decay depends on the quality and species of timber (Vissilia et al., 2010). Since the Joglo building use teakwood that has a good durability (JHS, 2007), and also due to good work of carpentry, well maintenance of residents and fairly good cross ventilation, explain that Joglo house type has high resistance against bio deterioration. In fact, the conservation state of the oldest groups at Keraton and Kotagede (royal houses) is better than the one of the group at Pundong, Pleret and Jetis (common houses).

\section{Earthquake damage}

The damage of Joglo buildings observed by a visual close-up inspection of the structural elements is divided into three main categories: columns-to-leg connection; joint between main columns and beams; and roof construction and its attachment with the core structure.

\section{Stone base and columns}

In our research we suggest a number of facts. Tenon of column's end works in securing the position of the columns on the foundation. It makes the structural system able to resist against seismic lateral forces even if columns are inclined (Figure 7a). The fatal damage of the joint between column and foundation occurred when some columns lacked the original tenons (Prihatmaji et al, 2011). This is observed more commonly on side structures rather than core structures (Figure 7b). These columns then easily slipped over the foundation causing total collapse of the structure (Figure 7c). In addition, the joint of column tenon and stone base is seriously damaged when the column's leg has decayed (JHS, 2007; Prihatmaji et al., 2010a). Due to the damage of the column's tenon, the joint failure also represents a critical criterion in terms of building stabilization after a seismic attack. 


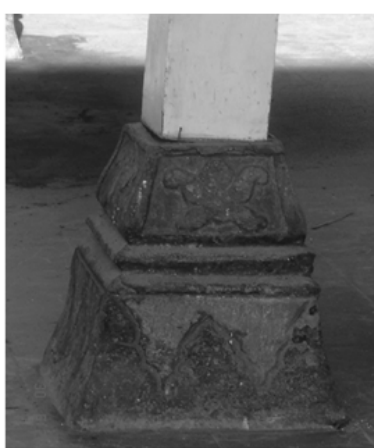

(a)

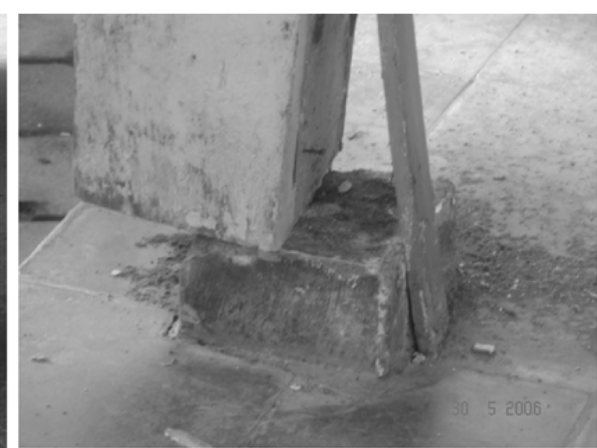

(b)

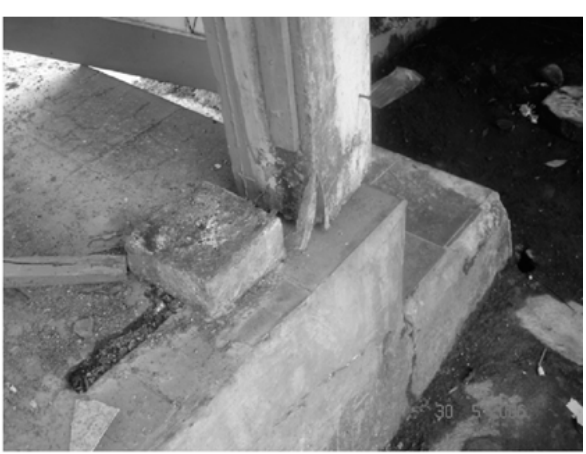

(c)

Figure 7. (a) The declined column, (b) Decaying of the column tenon, (c) The column stand on stone base without tenon.

\section{Columns and beams}

Mortise and tenon joints of the core structure are the primary elements providing rotation resistance against lateral forces. This type of joint provides the large deforming capacity through embedment behavior of column toward the beam.

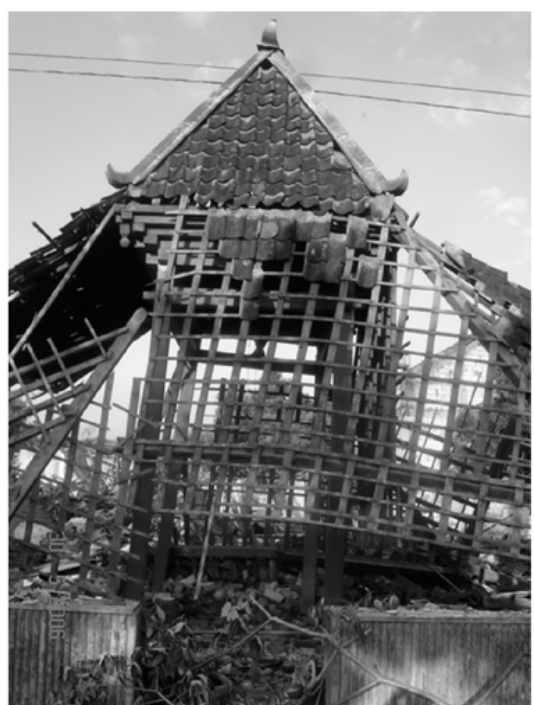

(a)

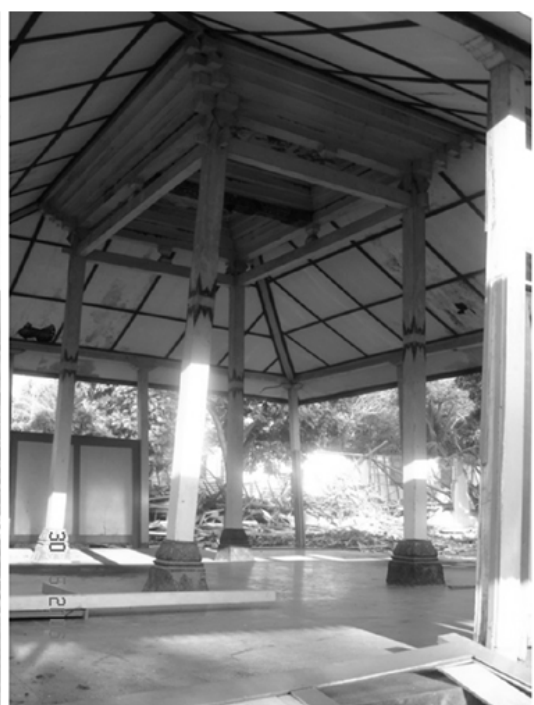

(b)

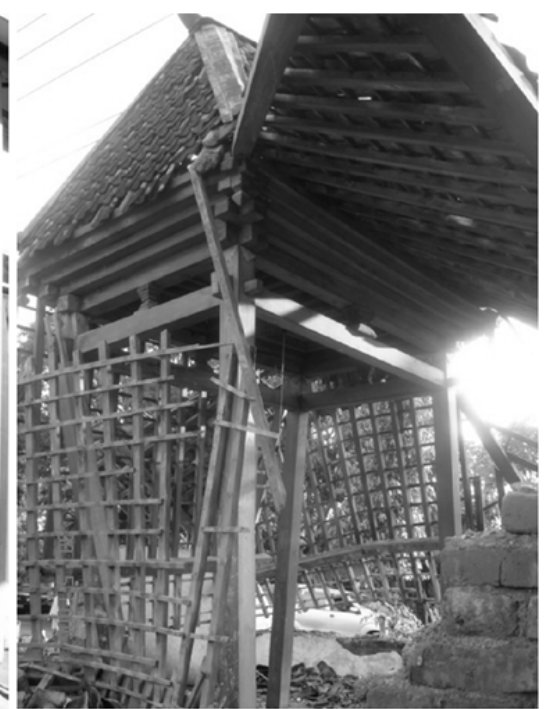

(c)

Figure 8a, b and c. State of Joglo's core structure after an earthquake.

Figure 8a-c, shows four columns that are severely inclined but still standing and securing human life. Hence, the role of joints is very important and significant. The most crucial damage between column and beam is observed at joints at the lower and upper beam. The joint of the long beam with the column gets damaged due to shear force and bending moment inside the mortise (Prihatmaji et al., 2011; Prihatmaji et al., 2010b). Furthermore, mortise of columns, into which a number of beams are inserted, may cause a fatal damage on the core structure.

Figure 9a shows that the lower beam transmits lateral forces to the column, causing shear failure between lower and upper beam, resulting in the damage of both the column and the beam. When the strength of the column is weaker than that of the joints, (e.g. due to dimension loss by decay or carving), the column failed to bend, without the beams being damaged (Figure 9b). This may result in a total collapse of the structure, as seen in Figure 9c. 


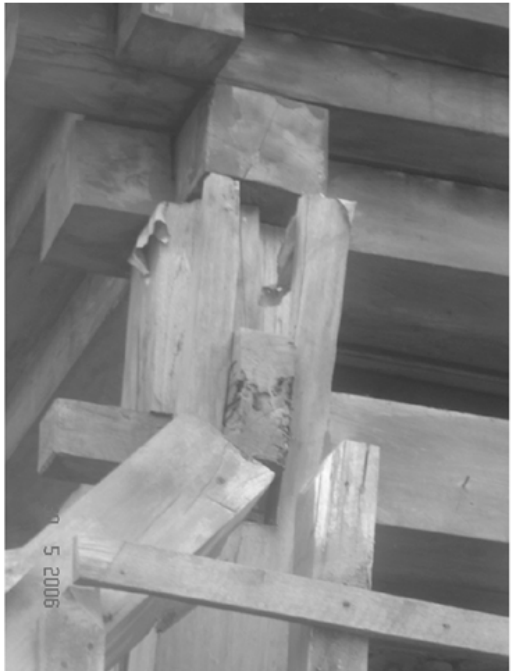

(a)

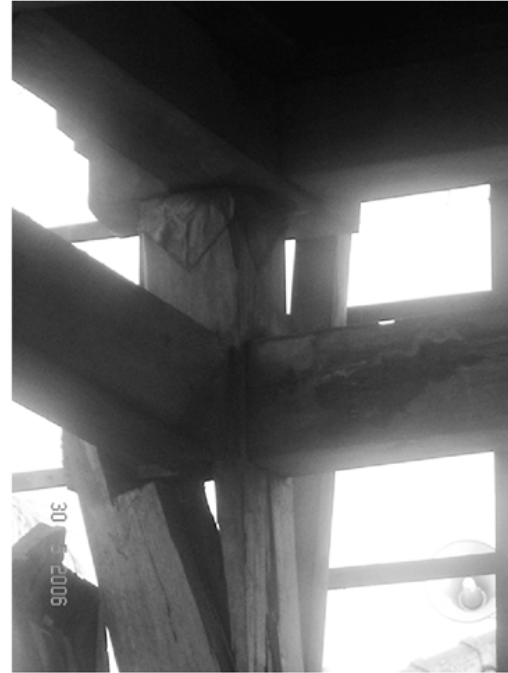

(b)

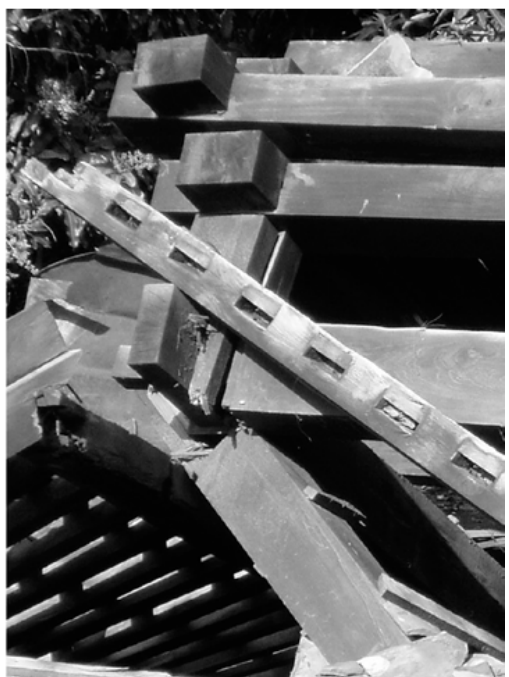

(c)

Figure 9. (a) Collapsed column-to-beam joint, (b) Broken joint, (c) Collapse of the core structure (@ JHS, 2006).

\section{Roof construction and attachment connection of side structure}

A clear indication of the roof construction's failure begins with the column slipping from the stone base. Due to differences of in-plane stiffness between outer and core structure, only outer structure is largely shaken when earthquake force is applied. This is because both in-plane stiffness and vertical stiffness of core structure are higher than that of outer structure. The rafters of the roof of the core and the outer structure have mortise inserted at the outermost band of rectangular beams. Figures 10a-b show the outermost band of rectangular beams in detail. The shape of the mortise is highly complicated (Figure 4b); basically consisting on a parallelogram with different angles. The rectangular shaped mortises are only at the middle of the beam, this is common for rafters placed around the corner of the roof flanking the hip rafters. The slip of column or any large deformation of the outer structure causes the rafter to be pulled out from the main beam. Hence, the outer structure becomes unstable and collapses.

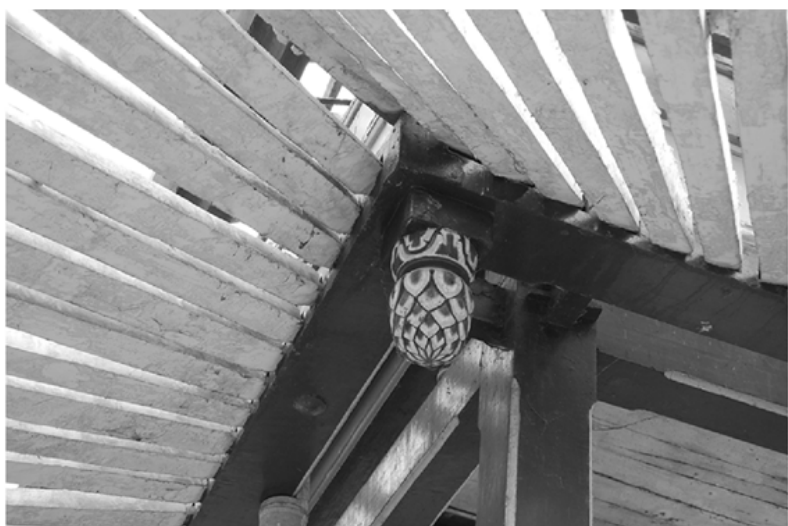

(a)

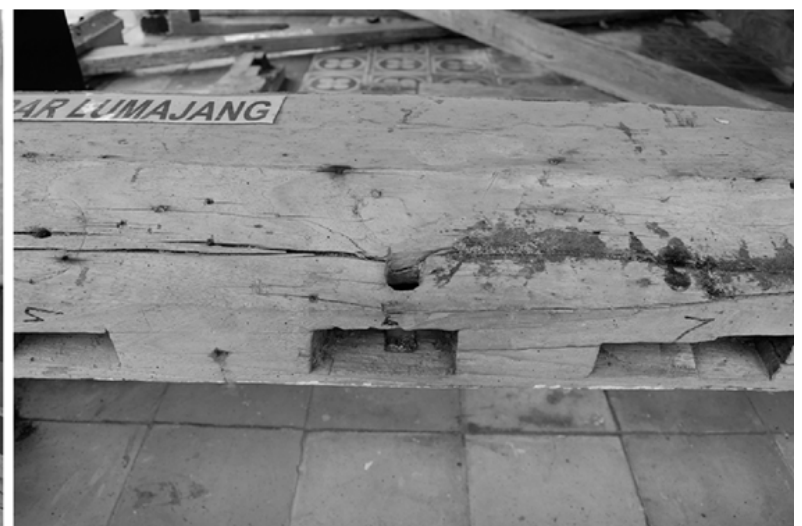

(b)

Figure 10. (a) The outermost band of rectangular beams, (b) mortises beam, where a series of rafter will be inserted.

\subsection{Levels of Joglo's Damage}

Figures 11a-d show different levels of damage in Joglo-type structures. We categorized them into 4 levels according to the gravity for the structural security and in order of appearance. Firstly, part of the side structure is selectively damaged while the core structure is still standing. This is due to the 
difference of strength performance, as shown in Figure 11a. Secondly, the side structure is partially collapsed or damaged while the core structure is slightly or not damaged (Figure 11b).
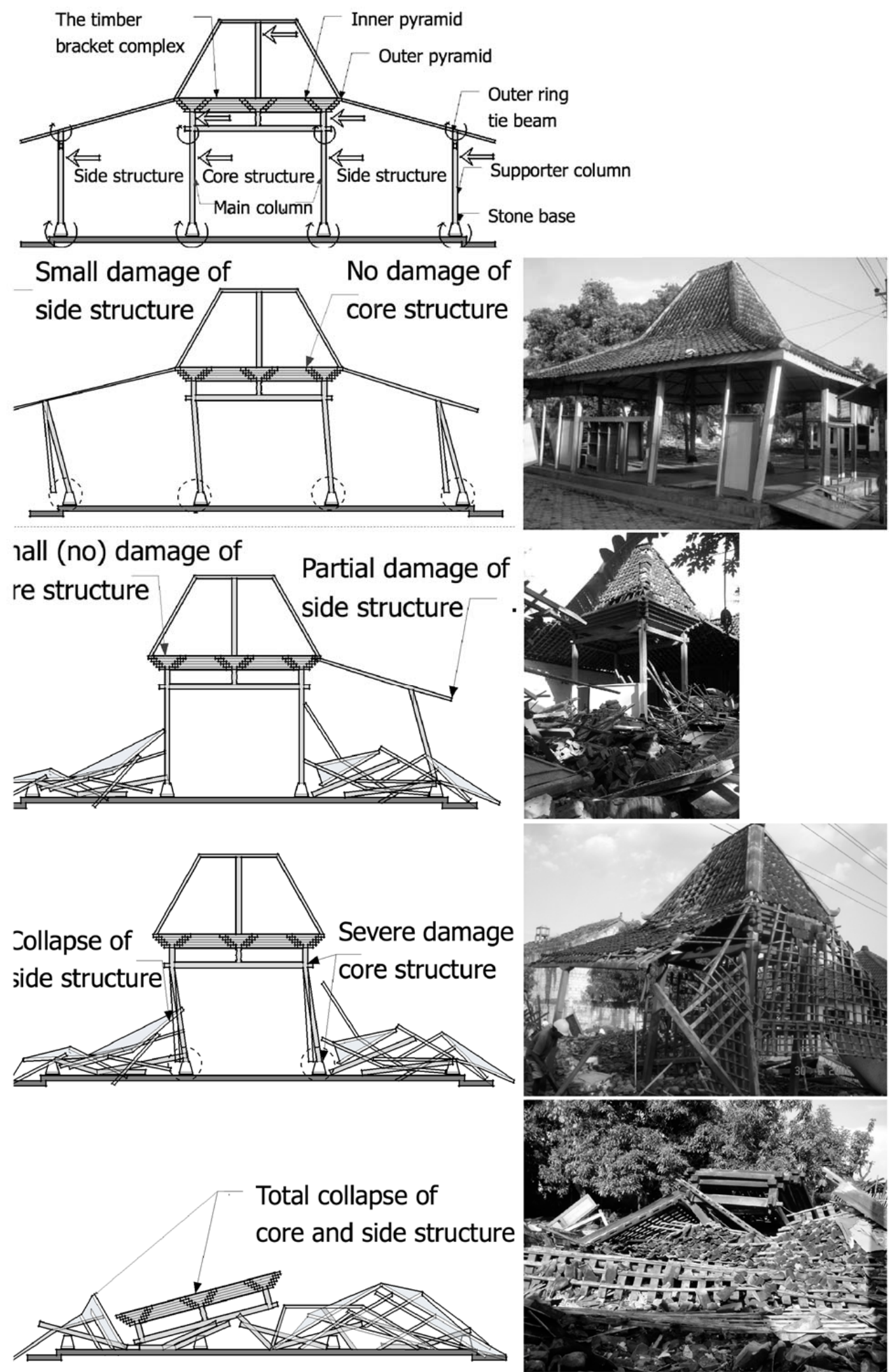

Figure 11. Levels of damage of the Joglo building (a) First level of damage, (b) Second level of damage (Figure 10b in right courtesy by Wulandari, 2006), (c) Third level of damage, (d) Fourth level of damage (Figure Figure 10a, b and d in left modified from Prihatmaji, 2010b and Ikaputra, 2011. Figure 10d in right modified from JHS, 2007). 
Figure 11c shows the third level of damage, which is identified by the collapse of the side structure, with the core structure remaining standing. At this stage, the core structure's columns are inclined but safe. This indicates the importance of the strength performance of the core structure for the security of the residents. At the fourth level of damage, the entire structure falls-down due to the collapse of core and side structure (Figure 11d).

The specific feature of the first level of damage involves broken mortise of columns, and slip between columns and stone foundations at the side structure, decline of column of side structure, and damage of outer ring joint. In the secondary level, joints between outer ring's beam and column are deformed or broken, and joints between inner ring beam at core structure and rafters broke, due to the rafter end connection being pulled out. In the third level, severe damages on the core structure are observed besides second level of damage. Severe damage on core structure is due to the main column's declining and breaking of the joint at lower beam of core structure. The main structures are totally collapsed including roof structures in the fourth level.

Table 3. Levels of damage and its mechanisms

\begin{tabular}{|c|c|c|}
\hline Levels of Damage & Number of Joglo Damage & Mechanisms of Damage \\
\hline 0 & - 4 houses $(20 \%)$ & - No damage \\
\hline $\mathrm{I}$ & - 4 houses $(20 \%)$ & $\begin{array}{c}\text { - Small damage of side structure } \\
\sim \text { Decline of side structure } \\
\sim \text { Damage of base joint of side column } \\
\sim \text { Damaged outer ring joint } \\
\text { - No damage of core structure } \\
\end{array}$ \\
\hline II & - 7 houses (35 \%) & $\begin{array}{l}\text { - Collapse (partial) of side structure } \\
\sim \text { Pull out of rafter end connection } \\
\text { - Small (no) damage of core structure }\end{array}$ \\
\hline III & - 2 houses $(10 \%)$ & $\begin{array}{c}\bullet \text { Collapse of side structures } \\
\bullet \text { Severe collapse of core structure } \\
\sim \text { Decline of main column } \\
\sim \text { Broken joint at lower beam of core structure } \\
\sim \text { Damage of base joint at core structure }\end{array}$ \\
\hline IV & - 3 houses $(15 \%)$ & - Total collapse of core and side structure \\
\hline
\end{tabular}

Table 3 lists levels and characteristics of damage. Categorization of level of damage focused on structural performance is important to carry out appropriate post earthquake intervention (rehabilitation and reconstruction) and to facilitate the management of next steps. Simple evaluation (no damage, lightly damage, partly collapse, heavily damage and totally collapse) is only needed in early steps to provide quick data for disaster management. Another state scale is needed for Joglo buildings as the following: resistant to earthquake, columns displaced, strong core structure and totally collapsed (Ikaputra, 2011).

Although the parameters depending on the features of the seismic input and the characteristics of the ground are decisive for the earthquake damage level, it is possible to select some structures located on similar grounds and subjected to comparable excitations (i.e. earthquake intensity). Previously mentioned set of buildings can be investigated, in the framework of a first qualitative step, to identify some sensitive parameters depending on the main structural characteristics. A thorough analysis shall be developed in the framework of a future work, carrying out parametric studies/calculations with different seismic scenarios (operational limit state, collapse limit state, for example) and varying the values of the most important parameters (parametric analysis).

\subsection{Relationship between Levels of Damage and Structural Proportion}

Table 4 reports the dimension measurements of structural components of the 10 selected Joglo houses.

Figures 12a-c show the mutual relationship between each specific size of Joglo structures listed in Table 4. The column's dimension (average of both width) (a) is associated with the width of the core structure (e) and the length of the core structure (f). The height of the column from floor surface to the 
centre of lower beam (d) relates with the distance between main columns and side columns (g). The height of the lower beam (b) corresponds to the width of the core structure (e).

Table 4. Result of measurement of structural components

\begin{tabular}{|c|c|c|c|c|c|c|c|c|c|}
\hline \multirow[b]{2}{*}{$\begin{array}{l}\text { No of } \\
\text { Joglo* }\end{array}$} & \multirow{2}{*}{$\begin{array}{c}\text { (a) } \\
\begin{array}{c}\text { Main } \\
\text { column } \\
\text { dimension } \\
(\mathrm{cm})\end{array}\end{array}$} & \multirow{2}{*}{$\begin{array}{c}\text { (b) } \\
\begin{array}{c}\text { Beam } \\
\text { height } \\
(\mathrm{cm})\end{array}\end{array}$} & \multirow{2}{*}{$\begin{array}{c}\text { (c) } \\
\begin{array}{c}\text { Height of } \\
\text { main } \\
\text { column } \\
(\mathrm{cm})\end{array}\end{array}$} & \multirow{2}{*}{$\begin{array}{c}\text { (d) } \\
\text { Height to } \\
\text { center of } \\
\text { beam } \\
(\mathrm{cm})\end{array}$} & \multirow{2}{*}{$\begin{array}{l}(\mathrm{e})^{* *} \\
\text { Main } \\
\text { column } \\
\text { to main } \\
\text { column } \\
\text { width } \\
\text { (cm) }\end{array}$} & \multirow{2}{*}{$\begin{array}{c}\text { (f) } \\
\text { Main } \\
\text { column } \\
\text { to main } \\
\text { column } \\
\text { length } \\
\text { (cm) }\end{array}$} & \multirow{2}{*}{$\begin{array}{c}(\mathrm{g})^{* * *} \\
\text { Main } \\
\text { column to } \\
\text { supporter } \\
\text { column } \\
\text { length } \\
\text { (cm) }\end{array}$} & \multicolumn{2}{|c|}{$\begin{array}{c}\text { Weight of roof } \\
\left(65 \mathrm{~kg} / \mathrm{m}^{2}\right)\end{array}$} \\
\hline & & & & & & & & $\begin{array}{c}\text { The } \\
\text { core } \\
\text { structure } \\
(\mathrm{kg})\end{array}$ & $\begin{array}{c}\text { The side } \\
\text { structure } \\
\text { (kg) }\end{array}$ \\
\hline 1 & 14.4 & 16 & 422 & 389 & 4.42 & 5.69 & 3.92 & 1634.7 & 8989.3 \\
\hline 2 & 14.5 & 14 & 448 & 407 & 4.25 & 6.51 & 3.67 & 1798.4 & 7879.3 \\
\hline 3 & 16 & 18 & 495 & 465 & 4.29 & 5.58 & 4.67 & 1556.0 & 12758.2 \\
\hline 4 & 16.35 & 16 & 529 & 493 & 4.56 & 6.36 & 3.77 & 1885.1 & 8314.5 \\
\hline 5 & 18 & 17 & 487 & 452 & 3.52 & 5.49 & 4.68 & 1256.1 & 12812.9 \\
\hline 6 & 18.15 & 21 & 538 & 492 & 4.43 & 5.34 & 3.66 & 1537.7 & 7836.4 \\
\hline 7 & 20.2 & 21 & 570 & 523 & 3.28 & 4.65 & 4.61 & 991.4 & 12432.5 \\
\hline 8 & 20.6 & 20 & 544 & 506 & 3.44 & 5.62 & 5.29 & 1256.6 & 16370.7 \\
\hline A & 28.25 & 28 & 661 & 625 & 3.43 & 5.65 & 4.6 & 1259.7 & 12378.6 \\
\hline B & 20.75 & 15 & 461 & 437.5 & 2.91 & 4.4 & 3.78 & 832.3 & 8358.7 \\
\hline
\end{tabular}

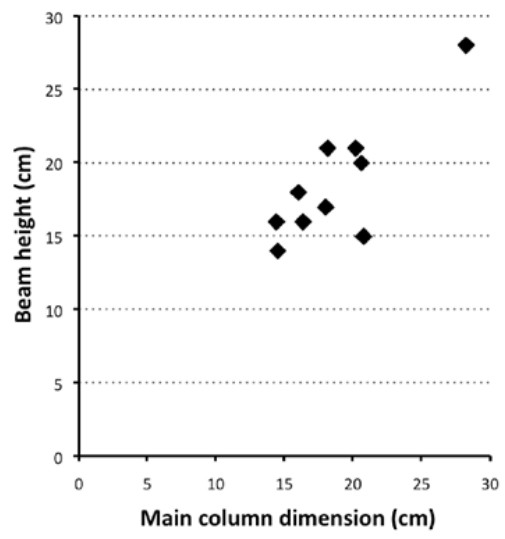

(a)

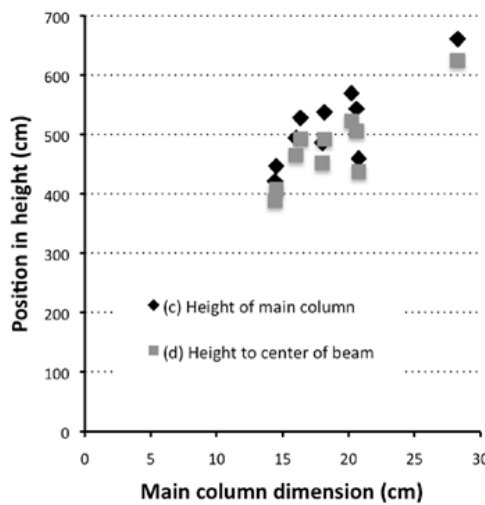

(b)

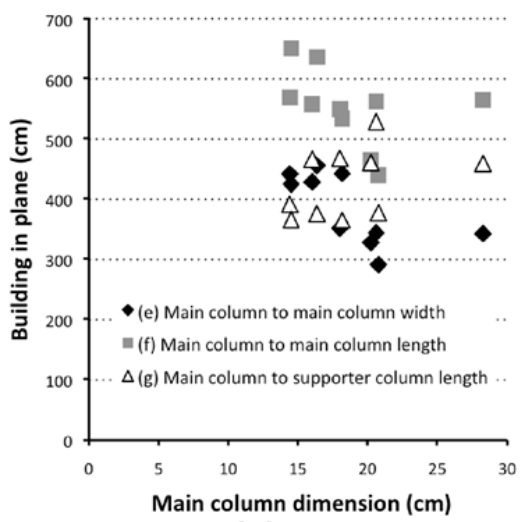

(c)

Figure 12. Relationship between each specific element's dimensions of the Joglo structure, (a) Beam height against main column dimension, (b) Position in height against main column dimension, (c) Building in plane against main column dimension.

From Figures 12a-b, a clear linear relationship can be observed between main column dimension (a) and beam height (b), as well as between height of main column (c) and height to center of beam (d). This indicates that the traditional carpenters have followed a common rule in construction to determine the dimensional proportion of the joints on the main column and its position in height. The proportion of the joints at the main column is about 1 to 1 , and is located at almost $92 \%$ of the height of the column.

In addition, when comparing between main column dimensions (a) and main column to main column width (e), main column to main column length (f) or main column to supporter column length (g), there was no such relationship, as shown in Figure 12c. This means that the dimension of the column and the size of the joint at the main column have not been decided according to the scale of 
the building in plane. Besides there is no clear rule for the size of the side structure in relation to the core structure.

Table 5. Proportion ratios between each structural dimension.

\begin{tabular}{|c|c|c|c|c|c|c|c|c|}
\hline \multirow[b]{2}{*}{$\begin{array}{c}\text { No } \\
\text { of } \\
\text { Joglo }\end{array}$} & \multirow[b]{2}{*}{$\begin{array}{l}\text { District } \\
\& \\
\text { Seismic } \\
\text { intensity } \\
\text { (MSK)* }\end{array}$} & \multirow[b]{2}{*}{$\begin{array}{l}\text { Distance } \\
\text { from } \\
\text { epicenter } \\
(\mathrm{Km})^{* *}\end{array}$} & \multirow[b]{2}{*}{$\begin{array}{c}\text { Geological } \\
\text { features } \\
\text { (Raharjo et al, } \\
\text { 1995) }\end{array}$} & \multirow[b]{2}{*}{$\begin{array}{c}\text { Level of } \\
\text { Damage**** }\end{array}$} & \multicolumn{4}{|c|}{ Proportion ratios } \\
\hline & & & & & $\begin{array}{l}\text { Main } \\
\text { column } \\
\text { dimension } \\
\text { (a) against } \\
\text { main } \\
\text { column to } \\
\text { main } \\
\text { width (e) }\end{array}$ & $\begin{array}{l}\text { Height of } \\
\text { beam (d) } \\
\text { against main } \\
\text { column to } \\
\text { supporter } \\
\text { column } \\
\text { length (g) }\end{array}$ & $\begin{array}{l}\text { Main column } \\
\text { dimension (a) } \\
\text { against Height } \\
\text { of beam (d) / } \\
\text { main column } \\
\text { to main width } \\
\text { (e) against } \\
\text { main column } \\
\text { to main } \\
\text { column length } \\
\text { (f) }\end{array}$ & $\begin{array}{l}\text { Beam height } \\
\text { (b) against } \\
\text { main } \\
\text { column to } \\
\text { main width } \\
\text { (e) }\end{array}$ \\
\hline 1 & & 18.8 & Volcanics & IV & 0.032 & 1.077 & 0.044 & 0.036 \\
\hline 2 & Pleret & 18.5 & (Holocene and & III & 0.033 & 1.221 & 0.050 & 0.033 \\
\hline 3 & $8.1-9.1$ & 17.7 & Miocene) & IV & 0.037 & 1.060 & 0.042 & 0.042 \\
\hline 4 & Jetis & 16.7 & Volcanics & III & 0.036 & 1.403 & 0.043 & 0.035 \\
\hline 5 & $7.7-8.3$ & 15.4 & (Holocene) & I & 0.051 & 1.041 & 0.054 & 0.048 \\
\hline 6 & Pundong & 14.3 & Volcanics & II & 0.041 & 1.470 & 0.049 & 0.047 \\
\hline 7 & $4.3-$ & 12.8 & (Holocene and & I & 0.062 & 1.236 & 0.058 & 0.064 \\
\hline 8 & 6.91 & 10.2 & Miocene) & II & 0.060 & 1.028 & 0.054 & 0.058 \\
\hline A & Keraton & 24.5 & Volcanics & 0 & 0.082 & 1.437 & 0.070 & 0.082 \\
\hline B & $\begin{array}{l}6.9- \\
6.99\end{array}$ & 23.1 & (Holocene) & 0 & 0.069 & 1.220 & 0.068 & 0.052 \\
\hline
\end{tabular}

Simple calculations on the values in Table 5 provide the proportion of structural elements; ratio between main columns width and span of core structure, ratio between main column height and span of side structure, ratio between section area of main column and area inside of core structure, and ratio between beam height and span of core structure.

Figures 13a-c compare the structural proportion and the levels of damage. As mentioned above, the joints on the main column are the principal elements resisting against earthquake attack and its performance is size-dependent. Nevertheless the size of the joint has no relation to the scale of building. Thus the ratio in size of building can be an indicator of earthquake resistance performance of Joglo buildings.

Figure 13a depicts the relationship between the ratios of the main column's dimension and short span of the core structure and level of damage. A declining tendency can be found, which indicates that the smaller the ratio becomes, the more damaged the structure is. Similarly, figure 13b shows a minor relationship between the ratio of the beam's height and the short span of the core structure and the levels of damage. While, figure 13c shows that there is no apparent relationship between the ratio of height-to-beam center and span of side structure and the levels of damage. This means that the scale of side structures has a low influence on the damage of the core structure.

The ratio of the vertical area of the main column and the horizontal area of the core structure could give better correspondence on the level of damage, as seen in figure 13d. A clear tendency is observed, showing that the smaller the ratio is, the more damage on structures is caused. Indeed the horizontal area of the core structure corresponds to the roof weight. The roof weight compresses that area and contributes to the instability in case of lateral earthquake forces. Therefore the ratio of the vertical section area (height of the main column) of the main column and horizontal area of core structure is a reliable indicator to estimate the earthquake resistance of Joglo structures. It can be used for selfchecking the Joglo structures (e.g. by the owner). Values lower than 0.05 indicate a serious danger for the structural security and a necessity of reinforcement. 


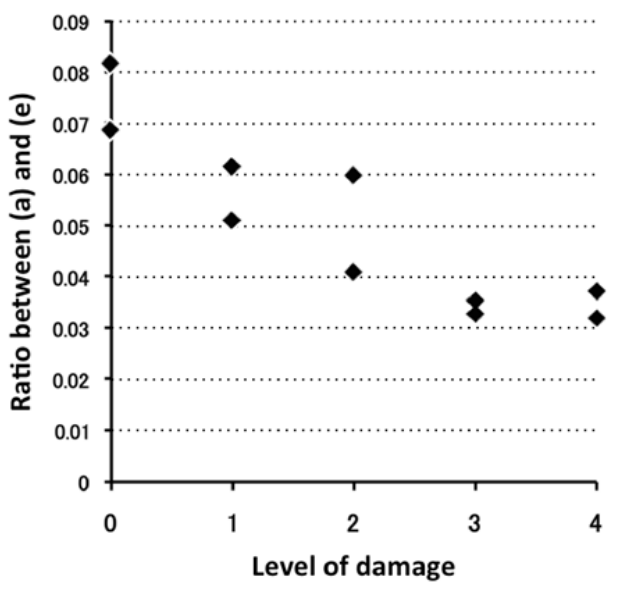

(a)

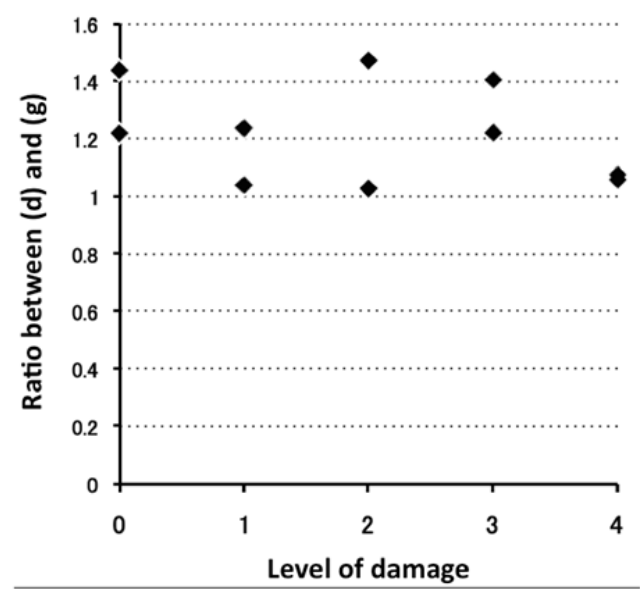

(c)

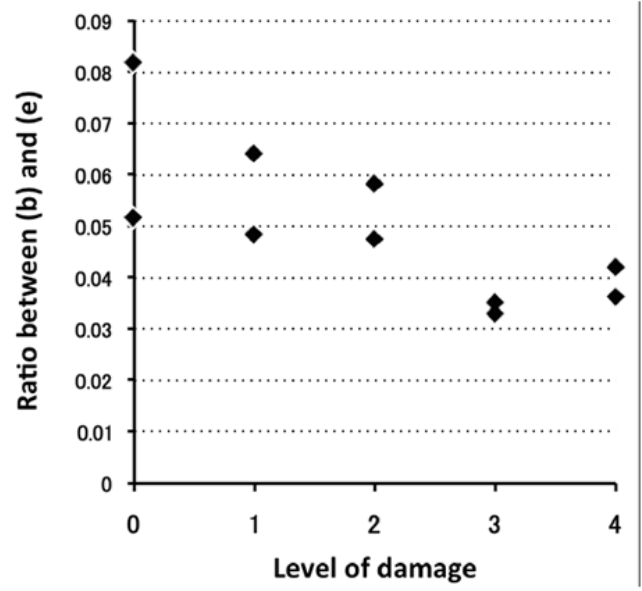

(b)

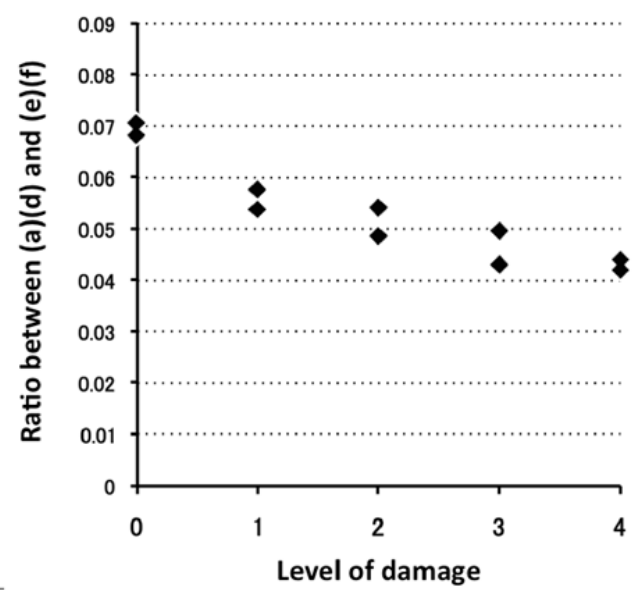

(d)

Figure 13. Comparison between structural proportion ratios and levels of damage, (a) Ration between (a) and (e) against level of damage, (b) Ratio between (b) and (e) against level of damage, (c) ratio between (d) and (g) against level of damage, (e) Ratio between (a/d) and (e/f) against level of damage.

\section{CONCLUSIONS}

Post-earthquake investigations of joglo damages due to the Java 6.3 Mw-earthquake were carried out in Yogyakarta and Bantul. In this paper we report the results of investigation and aim to verify the contributions of structural proportions to the level of damage on Joglo. The major findings are summarized below:

1. The dimensional proportion of the joint at the main column and its position in height follows traditional carpenter's common rule, while they have nothing to do with the scale of the building in plane.

2. Four levels of damages were categorized as follows: I) damage on the base joint of the side structure, II) fatal damage on the side-structure, III) destroyed core structure and IV) totally collapsed core structure. The side structure is relatively weak while the core structure confers the structural performance of whole Joglo buildings.

3. A strong relationship exists between the ratio of the vertical section area of the main columns and horizontal area of the core structure and level of damage; the smaller the ratio is, the higher the damage is extensive.

4. These samples of earthquake damaged wooden houses verify that structural proportion significantly contributes to simple estimation of earthquake-resistance performance of Javanese wooden houses. 
5. Little deterioration was found among the inspected Joglos. We suggest that use of teak wood, good work of carpentry, well maintenance from residents, and fairly good cross ventilation, contribute to earthquake resistance properties of Joglo.

The following recommendations are proposed to reduce the seismic vulnerability of the Joglo building, new as well as of the existing ones, of the risky area:

1. The Joglo houses with the unappropriate structural ratio need structural improvement to strengthen them from seismic attacks. Structural evaluation shall be done before reforming it, either completely or partially.

2. A regular maintenance, especially detail inspection on the condition of joint construction, roof construction and all columns from high moisture content is important. When decay is found, appropriate material should replace the useless one to create effective load-bearing capability of the existing structures.

3. A coordinated program to evaluate the vulnerability and associated risk of the existing Joglo building has to be carried out as soon as possible, adopting recent methodologies and techniques for retrofitting and strengthening.

\section{ACKNOWLEDGEMENTS}

The whole study was funded by the Directorate of Higher Education; Ministry of National Education Republic of Indonesia under DIKTI Scholarship Batch 3a. This work was supported by Grants-in-Aid for Scientific Research (S) 19106010 (Main Researcher: Professor Y. Suzuki) provided by Japan Society for Promoting Science (JSPS). Special gratitude is due to all of owner of Javanese wooden house in Bantul and Yogyakarta, Indonesia. The significant help and information that they have provided to the authors are deeply appreciated.

\section{REFERENCES}

Adishakti, L.T., 2008. Community Empowerment Program on the Revitalization of Kotagede Heritage District. In Vulnerable Cities: Realities, Innovations and Strategies. Edited by Tetsuo Kidokoro, Junichiro Okata, Shuichi Matsumura, Norihita Shima. Springer, Tokyo.

BAPPENAS, the Provincial and Local Governments of D.I. Yogyakarta, the Provincial and Local Governments of Central Java, and international partners, 2006. Report on Preliminary Damage and Loss Assessment, Yogyakarta and Central Java Natural Disaster.

Budiono, A., 2004. Review on Indonesian Building Regulations and Standards, Asian Forum for Wooden Architecture, Tokyo, Japan. forum.net/conference_2004/session_pdf/2-4\%20Indonesia\%20G\%20Budiono.pdf

Dogangun, A., Tuluk, O.I., Livaoglu, R., Acar, R., 2006. Traditional wooden buildings and their damages during earthquakes in Turkey. Engineering Failure Analysis 13, 981-996.

Elnashai, A.S., Kim, s.J., Yun, G.J, and Sidarta, D., 2006. The Yogyakarta Earthquake of May 27, 2006. MAE (Mid-America Earthquake Center) Center Report No. 07-02.

Ikaputra, 2011. Reconstructing Heritage Post Earthquake: The Case of Kotagede, Yogyakarta Indonesia. Journal of Basic and Applied Scientific Research, 1(11) 2364-2371.

Ismunandar K. R., 1997. Joglo: Arsitektur Rumah Tradisional Jawa (Joglo: Javanese Traditional Architecture); ed. 5, Dahara Prize, Semarang (in Bahasa Indonesia).

Jogja Heritage Society (JHS), 2007. Kotagede Heritage District, Yogyakarta, Indonesia: Home Owners's Conservation Manual, UNESCO Bangkok-UNESCO Jakarta.

Lourenco, P.B., Eduarda, L. (2006). Defects and moisture problems in buildings from historical city centres: a case study in Portugal. Building and Environment 41, 223-234

Murakami, H., 2007. Seismic Intensity Estimation by Questionnaire Survey, (H. Kawase, ed.) Report on the Damage Investigation of the 2006 Central Java Earthquake, Architectural Institute of Japan, 90-97.

Ohno, R., Marcillia, S.R., 2007. Analysis of Residents Condition and Behavior Based on Interview, (H. Kawase, ed.) Report on the Damage Investigation of the 2006 Central Java Earthquake, Architectural Institute of Japan, 98-113.

Paku Alam VI, G.K.B.R.A.A., 1977. Babad Pakualaman, (Lurah Jayengutara, ed. And translated by B.R.A Jurumertani), Ngayogyakarta. 
Piazza, M., Riggio, M. (2007). Typological and Structural Authenticity in Reconstruction: The Timber Roofs of Church of the Pieve in Cavalese, Italy. International Journal of Architectural Heritage, $1: 1,60-81$

Prihatmaji, Y.P., Kitamori, A., Komatsu K., 2011. Mechanical Analysis of Rotation Performance of Javanese Traditional Timber Joint. The Proceeding of International Symposium on Wood, Culture and Science 2011, August $2^{\text {nd }}-4^{\text {th }}$, Kyoto Japan.

Prihatmaji, Y.P., Kitamori, A., and Komatsu K., 2010a. Investigations on Damages of Javanese Wooden House Attacked by the Recent Earthquakes in Yogyakarta Area. The Proceeding of Japanese Wood Research Society (JWRS) Conference, March $17^{\text {th }}-19^{\text {th }}$, Miyazaki Japan.

Prihatmaji, Y.P., Kitamori, A., and Komatsu K., 2010b. The Impact of Tongue and Gulls Connection System for Earthquake Resistance for Javanese Wooden House. The Proceeding of the $11^{\text {th }}$ World Conference on Timber Engineering, June $20^{\text {th }}-24^{\text {th }}$, Trentino Italy.

Prihatmaji, Y.P., Kitamori, A., and Komatsu K., 2010c. Investigations on Earthquake Damages of Javanese Wooden House of Joglo Type in Relation with Their Structural Proportion. The Proceeding of Archietctural Institute of Japan (AIJ) Conference, September, Toyama Japan.

Ronald, A., Santosa, M., and Saragih, S., 1987. Joglo building: A Study of Construction, Proportion and Structure of Royal Houses in Yogyakarta. Research report at Gadjah Mada University, Yogyakarta (unpublished).

Santosa, R.B., and Prihatmaji, Y.P., 2010. Investigations on Earthquake Damages of Trajumas Hall in the Sultan's Palace Yogyakarta, The Proceedings of the Twelfth East Asia-Pacific Conference on Structural Engineering and Construction (12th EASEC), Hongkong, Procedia Engineering, edited by Lam Heung Fai, paper No. 338, pp. 2692-2698.

Siddiq, S., 2006. Bangunan Tahan Gempa Berbasis Estándar Nasional Indonesia (Earthquake Resistant Building based on National Standard of Indonesia), http://adm.dprd.jabarprov.go.id/internal/xadmin/upload/ppd/21601_VOL_8_NO_2_JULI_2006 _M-05.PDF. February 20th 2011. (in Bahasa Indonesia)

Sulistiana, I., 2007. Revitalization of Kotagede Post-earthquake 2006. Country report of Training Course on Cultural Heritage Protection in the Asia-Pasific Region. Preservation and Restoration of Wooden Structures. August $30^{\text {th }}-$ September $29^{\text {th }}$, 2007, Nara Japan.

Suwito, Y.S., 2009. Redesign of Bangsal Trajumas Kraton Yogyakarta. The Yogyakarta and Central Java Earthquake 2006: Recovery Status Report 01, Yogyakarta, 52-55.

Tjahjono, G., 1989. Cosmos, Center, and Duality in Javanese Architectural Tradition: The Symbolic Dimension of House Shapes in Kotagede and Surroundings (dissertation), University of California, Los Angeles.

United States Geological Survey (USGS), (http://earthquake.usgs.gov/earthquakes/recenteqsww/Quakes/usneb6.php), access at January $25^{\text {th }} 2007,13.41$ WIB.

Vissilia, A.M., Villi, M., (2010). Adobe and Timber Ties as Main Construction Materials for an Historic Greek Dwelling, International Journal of Architectural Heritage, 4:4, 295-319

Wahyudi, Heri EJ, 2008. Settelement and Housing Post Earthquake in Yogyakarta, 2006. Alumni Paper of Shelter Design and Development, Housing Development and Management, Lund University, Sweden. Source:

http://www.hdm.lth.se/fileadmin/hdm/alumni/papers/SDD 2007 242b/Didik-Indonesia.pdf, access at January $23^{\text {rd }}, 2011$.

Yahmo, I., 2007. Current State Of Wooden Architecture In Indonesia, Asian Forum for Wooden Architecture, Tokyo, Japan. http://www.iibh.org/AF_WoodenArchitecture/pdf/Indonesia_WORD.pdf

Yeo, SY., Hsu, MF., Chang, WS., Chen, JL., 2010. Life Cycle Assessment of Timber Components in Taiwan Traditional Temples. The Proceedings of the Twelfth East Asia-Pacific Conference on Structural Engineering and Construction (12th EASEC), January $26^{\text {th }}-28^{\text {th }}$, Hongkong. 